Vol. VII, Fasc. 1 e 2, p. $195-197$.

\title{
PTEROSAGITTA BESNARDI Van. \& Hosoe 1952 SYNONYM OF P. DRACO (Krohn 1853).
}

M. Vannucei $*$

K. Hosoe *

Pterosagitta besnardi was first described in 1952 , by Vannucei \& Hosoe, from material collected in the region of the island of Trindade and from the "Banco Jaseur", during a cruise of the "Baependi" and "Vega".

The following characters were then considered to be of specific rank: - absence of the giant bristles; shorter total length; caudal segment proportionally shorter; smaller number of hooks as well as anterior and posterior teeth; absence of a crest along the shaft of the hooks; short oval seminal vesicles (Vannucci \& Hosoe 1952, p. 23).

These differences on the whole and principally the absence of the giant bristles were considered sufficient to guarantee the erection of a new species.

Later on, studying the material collected in the region of the island of Fernando de Noronha $\left(32^{\circ} 25^{\prime}\right.$ Long. W $-3^{\circ} 50^{\prime}$ Lat. S), our attention was called by the presence of giant bristles on specimens otherwise similar to what had previously been called $P$. besnardi. The population from Fernando de Noronha has a large percentage of specimens with a well developed giant bristle area. It was this that suggested the necessity of studying over again the material from Trindade. A detailed study of the latter proved that there really is an area of sensory cells clearly different from the remainder portion of the collar epithelium, they are arranged in a shallow pit when the bristles are rudimentary or absent. The size and general aspect of these pits is similar to the common sensory buttons. We also found a few specimens with short tactile bristles and since the other differences are of smaller specific value, we believe that $P$. besnardi must be considered a synonym of $P$. draco. Answering to this question put to him by M. Vannucci and after examining some specimens from Trindade sent to him for this purpose, Dr. E. Ghirardelli kindly answered as follows: "If these ("specimens") were different only through the absence of bristles, one might think

* This paper was written while holding a fellowship granted by the National Research Council of Brazil (Conselho Nacional de Pesquisas). 
that they were lost, owing to their extreme fragility, but in the samples that you sent to me, I do not see the pits in which the bristles grow, or at least I do not see them as well developed as in the samples from other localities; this would make me believe in the real absence of the bristles themselves; in this case I would consider sufficiently justified the creation of the new species or at least of a sub-species, due to the importance systematists give to this character" (Ghirardelli, in litt.). Tokioka considers $P$. besnardi as a variety of $P$. draco (in litt.).

We finally arrived at the conclusion that in spite of the importance given by several authors to the giant bristles as a taxonomic character, they should not be considered neither of specific nor generic importance. $P$. besnardi cannot therefore be regarded as a new species but rather a population different from the previously described of $P$. draco, coming from other localities.

It must also be remembered that some authors do not even mention this character (Germain \& Joubin, 1916; Ramult \& Rose, 1946; Fowler, 1906) and do not even draw them in their figures.

Out of 133 specimens from the region of Trindade and "Banco Jaseur", $78,2 \%$ of the total had clear and transparent pits devoid of bristles, hardly distinguishable from the ordinary sensory buttons (Fig. 1 ) ; only $21,8 \%$ of the lot had pits provided with rudimentary or short bristles (Fig. 2).

In the collection from Fernando de Noronha there are rare specimens with giant bristles comparable to thoses of $P$. draco from $\mathrm{N}$. S. Wales (Tokioka, 1940, f. 9), even these, however, are not as long as the bristles of the specimens from the Mediterranean (Ghirardelli, 1950, p. 22). In the samples from Fernando de Noronha the frequencies were as follows: $31,2 \%$ had pits devoid of bristles (Fig. 3); $68 \%$ had rudimentary or short bristles. It seems therefore evident that the degree of development of the bristles is not a specific character but will probably have an important place in the study of the intra-specific variation of $P$. draco.

$P$. draco is probably a polytipic species. This is specially evident along the Atlantic, in fact, the specimens from the Trindade region $\left(20^{\circ}\right.$ Lat. S) are markedly different from those of the Mediterranean, to the point of having been considered a new species, while those taken further north in the Atlantic are morphologically intermediate. Thus the Mediterranean and South Atlantic races are linked by intermediate forms and mixed populations as has been found in the Middle Atlantic (Fernando de Noronha). This suggests the existence of a morphological gradient or cline along the area of distribution of the species.

$P$. draco, being a warm water species, the population taken in the Trindade region is probably a race living near the extreme range of distribution of the species with consequent greater divergence in the morphological traits.

Only statistical analysis of recently collected material will give the final answer to this question, there seems however to be no doubt that the specimens described under the name of $P$. besnardi belong to the same species as $P$. draco. 


\section{ACKNOWLEDGEMENTS}

It is a pleasure for us to express my thanks to Drs. E. Ghirardelli and T. Tokioka for going over our specimens and much helpful criticism.

\section{R E S M O}

Tendo sido encontrado na região de Fernando de Noronha abundante material morfològicamente intermediário entre Pterosagitta draco e $P$. besnardi, proveniente esta última da região da Tlha da Trindade, os caracteres anteriormente considerados como disjuntivos foram reestudados em material proveniente de ambas as zonas. As conclusões a que se chegou são: $P$. besnardi é sinônimo de $P$. draco. $2 .^{\circ}-P$. draco é muito provàvelmente uma espécie politípica. $30^{\circ}$ - Provàvelmente existe um gradiante morfológico no Atlântico, representando o material da Trindade o extremo sul da área de dispersão da espécie.

\section{R E F E R E N C S}

FOWLER, G. H., - 1906. The Chaetognatha of the Siboga Expedition. Monogr. n. ${ }^{\circ} 21$, p. $1-88,3$ t., 6 maps.

GERMAIN, L. \& L. JOUBIN - 1916. Chétognathes provenant des campagnes de "l'Hirondelle" et de la "Princesse-Alice" (1885-1910). Rés. Camp. Scient. Prince Albert ler Monaco, fase. 49, p. 1-118, 8 t.

GHIRARDELLI, E., - 1950. Osservazioni biologiche e sistematiche sui Chetognati della baia di Villefranche-sur-Mer. Boll. Pesea, Pise. Idrob., Anno 26, Vol. 5, p. $7-27$.

RAMULT, M. \& M. ROSE, - 1946. Recherches sur les Chaetognathes de la baie d'Alger. Bull. Soc. Hist. Nat. Afrique Nord, Vol. 36, p. 45-71.

TOKIOKA, T., - 1940. A small Collection of Chaetognaths from the Coasts of New South Wales. Rec. Austr. Mus., Vol. 20, p. 267-379.

VANNUCCI, M. \& K. HOSOE, - 1952. Resultados Científicos do Cruzeiro do "Baependí" e do "Vega" à Ilha da Trindade. Chaetognatha. Bol. Inst. Ocean., Vol. 3, p. 5-30, t. 1-4. 
Fotografia do colarinho de Pterosagitta draco, de procedências diversas, focalizando a região das cerdas gigantes.

1 - Exemplar proveniente da região da I. da Trindade. $a$ - área de inserção das cerdas gigantes, sem cerdas. $b$ - bolsão sensorial.

2 - Idem - c - com cerdas, porém curtas.

3 - Exemplar proveniente da região da I. de Fernando de Noronha. $d$ - cerdas ausentes.

$4-$ Idem $-e-$ cerdas presentes. 
VAnnucc, M. \& Hosoe, K., - Pterosagitta besnardi Van. \& Hosoe ... - EST. I
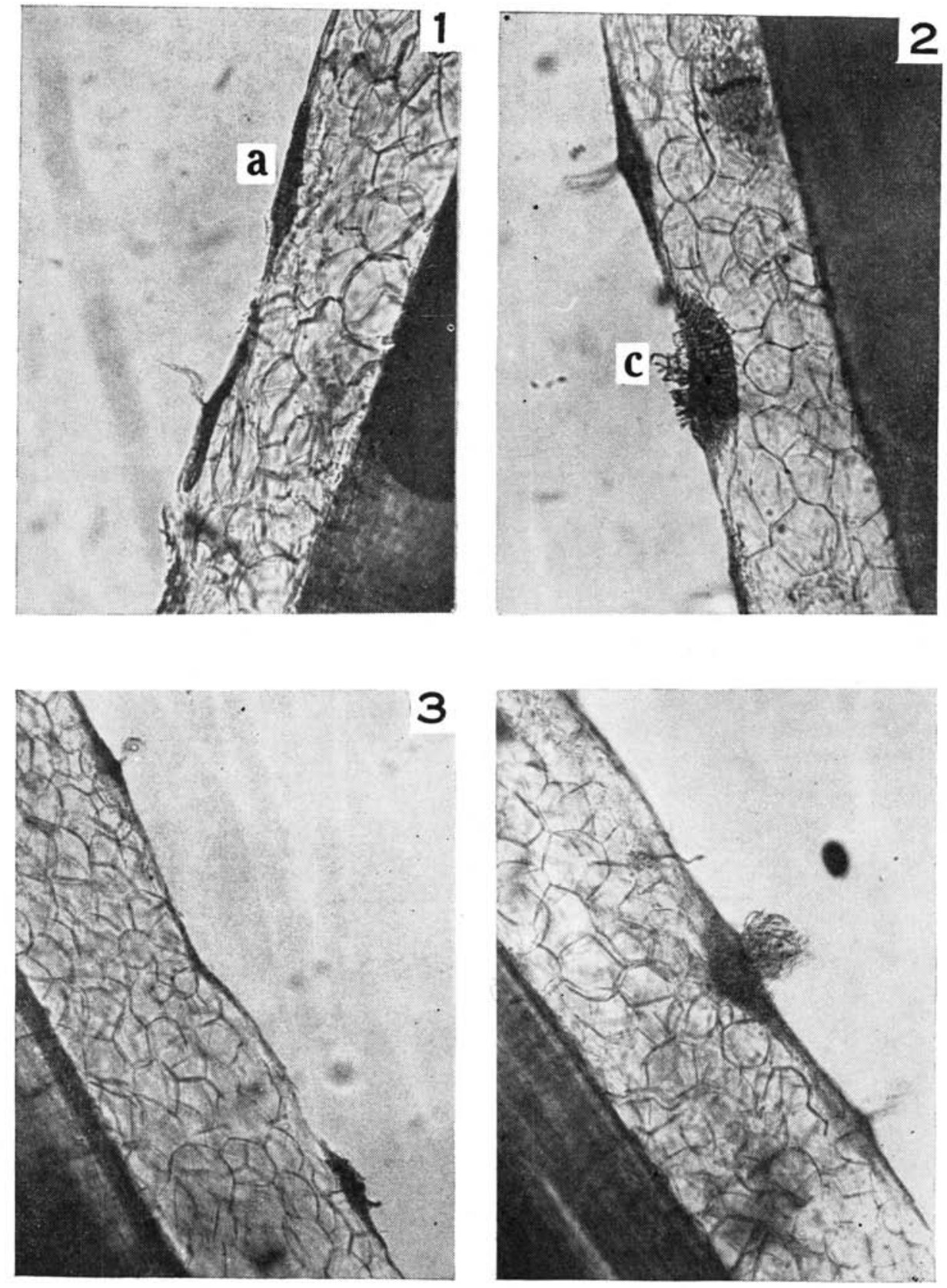